\title{
07 WTO accession and food security in China
}

\section{Tingsong Jiang}

After 15 years of long and difficult negotiations, China was admitted to WTO in November 2001. China made the most exceptional accession commitment in the history of the WTO and its predecessor, the General Agreement on Tariff and Trade (GATT). For example, China agreed to lower its average statutory tariff on industrial products to 8.9 per cent, while the rates for Argentina, Brazil, India and Indonesia were set as high as 30.9, 27.0, 32.4 and 30.9 per cent, respectively (Lardy 2002). For agricultural goods, China has agreed to have no agricultural export subsidies, and to limit its domestic support to farmers to $\mathbf{8 . 5}$ per cent of the production value, while other developing countries were allowed to have domestic support at a level of 10 per cent of production value.

Because of the expectation of possible compromise in the agricultural commitments and the comparative disadvantage of land intensive products, the adverse impact on agriculture of WTO accession caused great concern for Chinese policymakers and academics leading up to the accession. These concerns were all based on the prediction that the agricultural sector would be one of the most hard hit sectors and have been focused on two issues: food security and farmer incomes.

According to the World Food Summit, food security exists when all people, at all times, have physical and economic access to sufficient, safe and nutritious food to meet their dietary needs and food preferences for an active and healthy life. It means achieving four major components 
- ensuring that sufficient food is available

- maintaining relatively stable food supplies

- allowing access to food for those in need of it

- ensuring the biological utilisation of food.

Like other Asian countries, however, food security in China almost exclusively has meant food self-sufficiency, or grain self-sufficiency. A 95 per cent grain self-sufficiency level has been set as the target. The followings are some of the arguments made for China to maintain a certain rate of grain self-sufficiency and responses to these arguments.

First, China is a very large country in population terms and cannot rely on the world market for its food supplies. Brown (1995) painted a terrifying picture of China's food supply and demand to the effect that a food shortage in China would severely deplete world food supplies and hurt other developing countries. Although Brown's arguments were dismissed by the Chinese government and scholars, they increased concerns about China's food supply capacity.

Second, food is a special good and the independence of food supply has political and economic importance. Some people even fear the possibility of a food embargo as China has many ideological, political and strategic differences with major western powers. However, Lu (1997) and Yang (2000) point out that a food embargo against China is unlikely. Globally, food was often excluded from lists of embargoed commodities in the past because of humanitarian considerations. Moreover, a food embargo is difficult to apply and often means even higher economic costs for the countries that initiate the embargo.

Third, as many Chinese farmers earn their income exclusively from producing food, they may be badly hurt by cheaper food prices after WTO accession (Zhou 2001). This kind of impact has been seen previously in China and other developing countries. For example, in order to solve their food surplus problem in the early 1930s, a number of countries, including the United States, dumped a huge amount of food into the Chinese market and significantly depressed food prices. As a result, many Chinese farmers went bankrupt and China's grain sector was seriously injured (Xu 1996).

Chapter 6 (this volume) discusses the income effects, especially the 
regional income disparity impacts, of WTO accession. It was concluded that although China's WTO accession raises the real income and welfare of rural and urban households in all regions, regional income disparity and rural-urban inequality will worsen as the richer eastern region receives most of the welfare gains of accession. This chapter focuses on the food security issue.

\section{China's achievements in food security and food self sufficiency policies}

\section{China's achievements in food security}

China has made great progress in providing food security for its people since the economic reforms began in 1978. According to FAO statistics, the average per capita daily food consumption in China was only 2017 calories in 1979, well below the world average of 2500 and below the average of 2200 for other developing countries at that time. By 2001, it had increased by about 47 per cent to 2963 calories-above the world average of 2800 . Nutritional intake and food quality have also improved. China had made the greatest achievement in reducing undernourishment in both absolute and relative terms. During the period from 1990-92 to 1998-2000, China reduced the number of undernourished people by 70 million, or by 7 percentage points (FAO 2002).

Grain production and household incomes have increased as well. Total and per capita grain production increased at annual rates of 1.9 and 0.7 per cent, respectively, from 1978 to 2002. Per capita incomes of rural and urban households increased by 7.4 and 6.3 per cent per annum, respectively, over the same period (Table 7.1). The food self-sufficiency target has also been well maintained. In 2001, both total grain and total food self-sufficiency rates were above 95 per cent (Table 7.2).

These achievements were brought about by the agricultural economic reforms, especially the rural household responsibility system and market reform for production factors and agricultural commodities (Lin 1997). Between 1979 and 1984, when the household responsibility system began, the growth in agricultural total factor productivity (TFP) jumped to 5.1 
per cent per annum, compared to the -0.25 per cent per annum prevailing between 1952 and 1978. Agricultural TFP growth was kept at 3.9 per cent per annum from the late 1980s through to the early 1990s (Fan 1997). Market reform has also been remarkable. In 1978, the prices of 93 per cent of agricultural commodities were fixed by government and the prices of another 2 per cent were 'guided' by the government, leaving only 6 per cent to the market. In 1999, the composition was virtually reversed. The prices of 83 per cent of agricultural commodities were determined by the market (Table 7.3).

Although the growth in agricultural productivity has been remarkable, food consumption measured in terms of daily per capita calorie consumption has grown at an even higher rate (see Table 7.1). This difference implies that China's achievements in food security are mainly due to increases in household incomes.

\section{Food security policies in China}

China's food security policies have aimed at increasing grain self-sufficiency and food availability to households, especially urban households. These policies have included self-sufficiency policies, grain marketing policies, and grain reserve policies (Lohmar 2002). ${ }^{1}$

Grain self-sufficiency has been vigorously targeted since 1995, partly because of the 'wakeup call' by Brown (1995). Grain self-sufficiency is not only required at the national level, but also at local level. Under the Governor Grain Bag Policy (GGBP) established in 1995, provincial governors are required to be responsible for grain self-sufficiency in their jurisdictions. In order to fulfil their targets, governors have instructed their subordinates to increase sown areas, yields and grain production. As a result, almost every locality has its own grain production quota to fill.

The side effects of attempting to achieve grain self-sufficiency at local level are obvious. Increases in grain production have been achieved at the cost of efficiency losses as the practice ignores regional comparative advantages. This policy has been relaxed following WTO accession. At the national level, provinces are classified into three categories: major 
WTO accession and food security in China

\begin{tabular}{|c|c|c|c|c|}
\hline 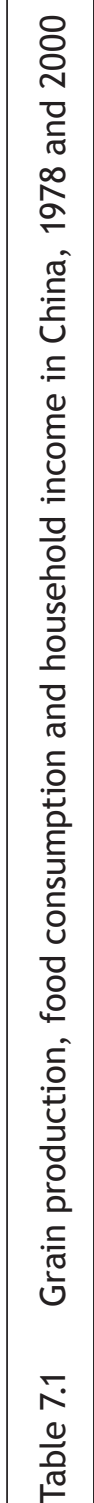 & 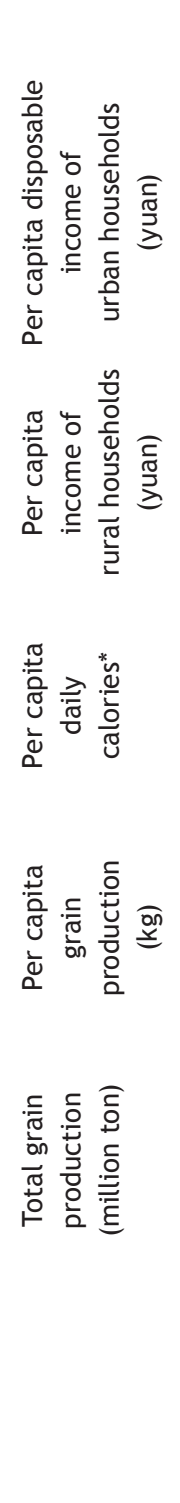 & œ & $\stackrel{\infty}{\stackrel{一}{\longrightarrow}}$ & 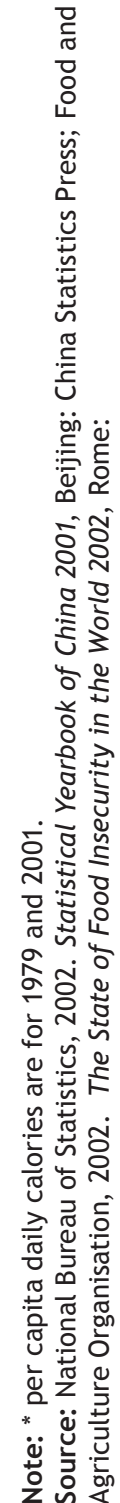 \\
\hline
\end{tabular}


Table 7.2 Food balance and self-sufficiency in China, 2001

\begin{tabular}{lrrrrrr}
\hline & Production & Imports & $\begin{array}{c}\text { Stock } \\
\text { change }\end{array}$ & & $\begin{array}{c}\text { Exports } \\
\text { utilisation } \\
\text { domestic }\end{array}$ & $\begin{array}{c}\text { Totalficiency } \\
\text { rate }\end{array}$ \\
Rice & & & & & 122,535 & 97.6 \\
Wheat & 119,596 & 694 & 4,353 & 2,109 & 102,640 & 91.5 \\
Corn & 93,876 & 2,286 & 7,530 & 1,052 & 119,338 & 95.7 \\
Pulses & 114,254 & 5,392 & 5,830 & 6,138 & 110 \\
Other grains & 5,127 & 263 & 8 & 739 & 4,659 & 110.0 \\
Oilseeds & 194,709 & 11,660 & -45 & 799 & 205,524 & 94.7 \\
Vegetable and fruits & 52,844 & 18,370 & -346 & 1,202 & 6,9667 & 75.9 \\
Other crops & 425,088 & 3,861 & -39 & 7,618 & 421,292 & 100.9 \\
Forest food & 88,854 & 282 & 0 & 4 & 89,133 & 99.7 \\
Livestock & 2,444 & 377 & -3 & 791 & 2,027 & 120.6 \\
Fishery & 107,239 & 4,793 & 5 & 2,366 & 109,671 & 97.8 \\
Food processing & 48,982 & 6,047 & 15 & 3,174 & 43,969 & 111.4 \\
Total grains & 56,821 & 6,021 & -563 & 1,407 & 60,873 & 93.3 \\
Total food & 527,562 & 20,295 & 17,676 & 10,837 & 554,696 & 95.1 \\
& $1,309,834$ & 60,046 & 16,745 & 27,399 & $1,351,328$ & 96.9 \\
\hline
\end{tabular}

Note: Production, imports, exports, stock change and utilisation are in million metric tons, and the self-sufficiency rates are in per centages.

Source: Food and Agriculture Organisation 2003. FAO STAT, Rome: Food and Agriculture Organisation, available online at http://www.fao.org.

Table 7.3 Agricultural commodity price reform in China, 1978-99

\begin{tabular}{lccc}
\hline & & & \\
Year & Market determined & State guided & State fixed \\
1978 & 6 & 2 & 93 \\
1985 & 40 & 23 & 37 \\
1987 & 54 & 17 & 29 \\
1991 & 58 & 20 & 22 \\
1995 & 79 & 4 & 17 \\
1999 & 83 & 7 & 9 \\
\hline
\end{tabular}

Source: Lardy, Nicholas R., 2002. Integrating China into the Global Economy, Washington D.C.: Brookings Institution, Washington, DC:25. 
grain production provinces, provinces with balanced grain production and consumption, and net grain importing provinces. Major grain production provinces have comparative advantage in grain production and are thus encouraged to increase grain production. Other provinces are allowed to import grains from other regions and overseas to meet the local demand.

Associated with the grain self-sufficiency and availability policies are grain marketing and pricing policies. The Chinese government has intervened in grain production and markets using procurement quotas and contracts and different types of prices through the network of state owned grain bureaus and stations. Before the rural reforms began in 1979, the goals of these policies were to produce ample and cheap food for urban residents and to export farm products, to earn hard currency for importing advanced technology and equipment, and to develop industries in urban areas.

Since the economic reforms began, grain marketing and pricing policies have been significantly changed. ${ }^{2}$ Policy has been focused on improvement of farmers' incomes and long term food security and self-sufficiency (Ke 1999). The government attempts to counter price volatility through government procurement prices and sales prices: in a year of bumper crops the procurement price sets a floor price so that farmers are not hurt by falling market prices; while in a year of poor harvests, the government sells reserves to cap the soaring market price.

However, such price stabilisation practices send the wrong signal to farmers and make the situation even worse, as evidenced by the 'grain surplus crisis' in recent years. In a bid to increase grain production and farmers' incomes, the government significantly raised the procurement prices in 1994 and 1996-by 40 per cent each time; as a result, grain production kept increasing. In 1998, the total grain output reached 504.5 million tons, well above the upper range of the target set for the year 2000. Although the open market price started falling from the end of 1997, as the higher government procurement price is 'guaranteed', output failed to adjust. As a result, on the one hand some farmers faced difficulties in selling their grains, resulting in political difficulties. On the other hand, the agency implementing the price protection policy, the state owned grain sector, 
accumulated huge losses. An estimate by Zhang and Li (1998) indicates that the amount of non-performing loans owed by the state grain sector to the Chinese Agricultural Development Bank reached 21.4 billion yuan.

These huge losses by the state grain sector were completely unacceptable, and grain marketing and distribution system reforms initiated in May 1998 were designed to reduce the losses. Despite the continuing assertion that the government buys the grain from farmers at protected prices, the new policies required state grain agencies to sell grain at a price that covers the full costs incurred and preferably with a small profit margin. The state grain agencies were also asked to improve their operational efficiency through redundancies and other measures.

The original idea was gradually to liberalise the grain markets so that government procurement prices would move close to market prices. However, due to the fundamental flaw in the design of the policy, that is, that the state grain sector was asked to carry out two conflicting duties-to act as a government agency implementing the protection price policy and to achieve financial soundness as a commercial entity-after one year the declining trend in grain prices increased and the government subsidy continued to soar. The government realised the problem and slightly changed the policy in mid May 1999. The remedies included reducing the scope of the price support coverage and the support price levels and allowing grain processing and feed industries to purchase grain directly from farmers.

Another direct approach to achieving food security has been the state grain reserve policy. The national government controls a large amount of reserve grain stocks. However the volume of stocks held is a state secret. The state stocks are managed by the State Administration for Grain Reserves (SAGR) and held by the grain bureaus. When there is a grain shortage, reserves are sold to put downwards pressure on prices. However, the management of state held stocks is seen as being too bureaucratically constrained to effectively reduce price volatility (Lohmar 2002). Moreover, maintaining the stockpile is expensive. Nyberg and Rozelle (1999) estimate that the costs of carrying over one ton of wheat, rice and corn were about US\$42, US\$6 and US\$39, respectively, being equivalent to over 20 per cent of the price of each commodity on the world market. 


\section{The impact on agricultural production and food security of WTO accession}

\section{China's WTO accession commitments in agriculture}

China's commitments in agriculture are more far reaching than those in manufactured goods. They include the reduction in tariff rates, adoption of a tariff rate quota system, limits on domestic support and on export subsidies for agricultural products, and the elimination of some technical trade barriers.

China agreed to reduce the average statutory tariff rate for agricultural products from 22 per cent to 15 per cent by January 2004. It also agreed to adopt the tariff rate quota system for key agricultural products such as wheat, rice and corn. Within the specified import quota, which is scheduled to increase over time, the tariff rate for these three grain products is only 1 per cent (Table 7.4). The state owned agricultural trading firms no longer enjoy the monopoly power they previously had, as private firms have been allowed to enter the foreign trade market and to import any unfulfilled quota left by the state owned firms.

However, these commitments do not necessarily lead to significant adverse impacts on agricultural production as China already had relatively low protection on agriculture. For example, the nominal rates of protection for rice, vegetables and fruits and meats are negative (Table 7.5). This situation was partly due to the history of taxing agriculture to subsidise industrial development and partly due to the effort of reducing protection along with the WTO accession negotiations.

\section{Overall impacts of WTO accession}

Simulations of the impacts of WTO accession were carried out using the closure of no control on the trade balance; that is, the exchange rate is fixed and the trade balance is endogenous. The macroeconomic impacts of China's WTO accession are summarised in Table 7.6. Several points can be drawn from the simulation results.

First, China has an overall gain from WTO accession. Real GDP, consumption and the utility level increase, by $0.4,1.0$ and 0.8 per cent, 
Table 7.4 Tariff rate quotas and imports of major agricultural products, million metric tons

\begin{tabular}{|c|c|c|c|c|c|c|c|}
\hline Commodity & $\begin{array}{l}\text { Initial } \\
\text { quota }\end{array}$ & $\begin{array}{l}\text { Ultimate } \\
\text { quota }\end{array}$ & $\begin{array}{l}\text { In quota } \\
\text { tariff rate }\end{array}$ & $\begin{array}{l}\text { Out quota } \\
\text { tariff rate }\end{array}$ & 1998 & 1999 & 2000 \\
\hline Wheat & 7.884 & 9.636 & 1 & 65 & 1.55 & 0.45 & 0.88 \\
\hline Corn & 5.175 & 7.200 & 1 & 65 & 0.25 & 0.07 & \\
\hline Rice & 3.325 & 5.320 & 1 & 65 & 0.26 & 0.17 & 0.24 \\
\hline Soybean oil & 2.118 & 3.587 & 9 & $63.3 \rightarrow 9$ & 0.83 & 2.08 & 1.79 \\
\hline Palm oil & 2.100 & 3.168 & 9 & $63.3 \rightarrow 9$ & & & \\
\hline Rapeseed oil & 0.739 & 1.243 & 9 & $63.3 \rightarrow 9$ & & & \\
\hline Sugar & 1.680 & 1.945 & $20 \rightarrow 15$ & $71.6 \rightarrow 50$ & & 0.42 & 0.64 \\
\hline Wool & 0.253 & 0.287 & 1 & 38 & & 0.199 & \\
\hline \multicolumn{8}{|l|}{0.301} \\
\hline Cotton & 0.781 & 0.894 & 1 & $61.6 \rightarrow 40$ & 0.21 & 0.05 & 0.05 \\
\hline $\begin{array}{l}\text { Source: Proto } \\
\text { National Burea } \\
\text { Press, Beijing. }\end{array}$ & $\begin{array}{l}\mathrm{n} \text { the A } \\
\text { Statisti }\end{array}$ & $\begin{array}{l}\text { ssion of th } \\
\text { 2002. Stat }\end{array}$ & $\begin{array}{l}\text { People's Re } \\
\text { stical Yearbc }\end{array}$ & $\begin{array}{l}\text { public of Ch } \\
\text { ok of China }\end{array}$ & $\begin{array}{l}\text { a, Sch } \\
001, \mathrm{C}\end{array}$ & $\begin{array}{l}\text { ule CLII } \\
\text { a Statis }\end{array}$ & \\
\hline
\end{tabular}

Table 7.5 Nominal rates of protection (tariff or tariff equivalent) for agricultural products in China, 1995-01

\begin{tabular}{lccc}
\hline & 1995 & 1997 & 2001 \\
Rice & -5 & -5 & -3 \\
Wheat & 25 & 17 & 12 \\
Coarse grains & 20 & 28 & 20 \\
Vegetables \& fruits & -10 & -8 & -4 \\
Oilseeds & 30 & 28 & 32 \\
Sugar & 44 & 42 & 40 \\
Cotton & 20 & 17 & 17 \\
Meats & -20 & -19 & -15 \\
Milk & 30 & 30 & 30 \\
\hline
\end{tabular}

Source: Anderson, Kym, Jikun Huang, and lanchovichina, E., 2002b, Long-run impacts of China's WTO accession on farm-nonfarm income inequality and rural poverty, Memo, Centre for International Economic Studies, University of Adelaide, Table 6. 
respectively. The welfare improvement, measured by the equivalent variation (EV), amounts to 58.2 billion yuan.

Second, the tariff reductions lead to lower prices of imports, which, in turn, result in lower overall prices. The consumer price index (CPI) and GDP deflator decline by 2.2 and 1.8 per cent, respectively. Because of the cheaper domestic prices, the terms of trade decline by 0.4 per cent.

Third, both imports and exports increase after the tariff cut by 19.0 and 11.1 per cent, respectively. As imports increase more than the exports, the trade balance declines by about 34 billion yuan.

Fourth, the impacts of WTO accession are not evenly distributed. Crops, food processing, motor vehicle and parts, and the machinery sectors are

Table 7.6 Macroeconomic impact of WTO accession

\begin{tabular}{lcccc}
\hline & Eastern & Central & Western & National \\
Real GDP (per cent) & 0.703 & -0.114 & 0.275 & 0.436 \\
Real consumption (per cent) & 1.694 & 0.19 & 0.218 & 1.021 \\
Utility (per cent) & 1.093 & 0.317 & 0.402 & 0.790 \\
EV (billion yuan) & 51.397 & 3.627 & 3.179 & 58.203 \\
CPI (per cent) & -2.118 & -2.019 & -2.477 & -2.157 \\
GDP deflator (per cent) & -1.673 & -1.783 & -2.500 & -1.831 \\
$\quad$ Changes in trade balance (billion yuan) & & & -33.955 \\
Terms of trade (per cent) & & & & -0.416 \\
Imports (per cent) & & & & 19.042 \\
Exports (per cent) & & & & 11.096 \\
Sectoral output & & & & \\
Crops & -0.674 & -0.294 & -0.399 & -0.490 \\
Other agriculture & 0.637 & 0.257 & 0.466 & 0.487 \\
Mining & -1.484 & 1.270 & 2.943 & 0.160 \\
Food processing & -5.679 & -1.751 & -5.332 & -4.404 \\
Light industry & 7.188 & -0.217 & 1.129 & 5.341 \\
Chemicals & -1.922 & -0.931 & -0.680 & -1.556 \\
Motor vehicles and parts & -17.612 & -14.658 & -10.814 & -16.035 \\
Machinery & -3.590 & -0.865 & 0.641 & -2.516 \\
Electronic and electrics & 6.549 & -0.736 & 3.736 & 5.737 \\
Construction & 0.426 & 1.033 & 1.162 & 0.687 \\
Service & 0.774 & -0.159 & 0.132 & 0.481 \\
& & & & \\
\hline
\end{tabular}

Source: Author's CERD simulation 
adversely affected while the other sectors benefit. The motor vehicle and parts sector is the hardest hit while light industry benefits most.

In terms of regional distribution, almost all the benefits go to the eastern coastal region. This is because the eastern region has the highest proportion of booming sectors. This pattern of impact implies that the regional income disparity worsens after WTO accession. Chapter 6 (this volume) discusses this issue in more detail.

\section{Impact of WTO accession on agriculture and food security}

The impacts of WTO accession on production, exports, imports and selfsufficiency of agricultural products are reported in Tables 7.7-7.10. Although agricultural imports and exports change significantly, the imported volume is still within the quota, and the contraction of output is limited. For most grains, the reduction in output is less than 1 per cent. Consequently, the impact on grain and food self-sufficiency is also limited and the target rate of 95 per cent self-sufficiency is likely to be achieved.

Grains production in the eastern region declines the most, while that in the central region declines the least. This result is in line with the comparative advantage of regional agricultural production. Compared to the eastern region, the central region has a relatively abundant labour force and land resources. Compared to the western region, the central region has more favourable weather conditions, and arable land resources are also relatively abundant.

However, food security may still be an issue even if the self-sufficiency target is achieved. This is because the benefits and costs of accession are not evenly distributed across regions and households. Even if the overall benefit is larger than the cost, for those engaged mainly in the contracting sectors, food insecurity caused by the reduction in income may be a problem. This is especially important for rural households in inland regions. For example, the real wage in agricultural sectors in the central region declines after the WTO accession (Table 7.11). ${ }^{3}$ Table 7.11 also shows that rural household income increases to a smaller extent than urban household income; that is, the rural-urban income inequality worsens. 
Table 7.7 Impact of WTO accession on agricultural production (per cent)

\begin{tabular}{llllc}
\hline & Eastern & Central & Western & National \\
Rice & -0.318 & -0.169 & -0.227 & -0.242 \\
Wheat & -1.072 & -0.367 & -0.523 & -0.690 \\
Corn & -1.800 & -0.563 & -0.813 & -1.072 \\
Pulse & -1.125 & -0.379 & -0.544 & -0.588 \\
Other grains & -1.136 & -0.385 & -0.549 & -0.720 \\
Cotton & -1.226 & -0.327 & -0.499 & -0.624 \\
Oilseeds & -1.981 & -0.537 & -0.801 & -1.313 \\
Vegetable \& fruit & -0.019 & 0.006 & -0.024 & -0.015 \\
Other crops & -0.478 & -0.127 & -0.205 & -0.356 \\
Forestry & 0.696 & 0.768 & 0.854 & 0.753 \\
Livestock & 1.523 & 0.298 & 0.555 & 0.892 \\
Fishery & -0.989 & -0.228 & -0.100 & -0.798 \\
Other agriculture & 0.223 & 0.222 & -0.243 & 0.126 \\
Processed food & -5.679 & -1.751 & -5.332 & -4.404 \\
& & & & \\
\hline
\end{tabular}

Source: Author's CERD simulation

Table 7.8 Impact of WTO accession on agricultural exports (per cent)

\begin{tabular}{lcccc}
\hline & Eastern & Central & Western & National \\
Rice & 9.253 & 9.629 & 10.787 & 9.511 \\
Wheat & 9.898 & 10.037 & 11.357 & 10.118 \\
Corn & 10.075 & 9.994 & 11.475 & 10.201 \\
Pulse & 9.913 & 10.028 & 11.367 & 10.143 \\
Other grains & 9.888 & 10.008 & 11.339 & 10.134 \\
Cotton & 9.955 & 10.018 & 11.344 & 10.193 \\
Oilseeds & 10.209 & 10.051 & 11.546 & 10.187 \\
Vegetable \& fruit & 9.574 & 10.027 & 11.090 & 9.740 \\
Other crops & 9.741 & 10.048 & 11.210 & 9.915 \\
Forestry & 8.018 & 8.247 & 9.740 & 8.219 \\
Livestock & 11.295 & 10.169 & 11.981 & 10.937 \\
Fishery & 11.477 & 9.894 & 11.253 & 10.868 \\
Other agriculture & 9.013 & 9.240 & 11.394 & 9.405 \\
Processed food & 3.931 & 7.377 & 4.739 & 4.938 \\
& & & & \\
\hline
\end{tabular}

Source: Author's CERD simulation 
Table 7.9 Impact of WTO accession on agricultural imports (per cent)

\begin{tabular}{lrrrr}
\hline & & & & \\
& Eastern & Central & Western & National \\
Rice & -7.908 & -7.743 & -8.635 & -7.969 \\
Wheat & 31.737 & 33.813 & 32.069 & 32.055 \\
Corn & 66.536 & 71.405 & 68.605 & 67.630 \\
Pulse & 32.460 & 34.700 & 32.904 & 33.142 \\
Other grains & 32.521 & 34.760 & 32.970 & 32.880 \\
Cotton & 53.627 & 56.787 & 54.684 & 54.474 \\
Oilseeds & 83.812 & 90.133 & 86.939 & 84.771 \\
Vegetable \& fruit & -7.466 & -7.576 & -8.326 & -7.543 \\
Other crops & 15.097 & 15.871 & 14.705 & 15.099 \\
Forestry & -4.753 & -4.531 & -5.692 & -4.730 \\
Livestock & 2.255 & 0.647 & -0.857 & 1.702 \\
Fishery & -7.215 & -2.421 & -4.781 & -6.632 \\
Other agriculture & 325.428 & 323.875 & 307.226 & 324.185 \\
Processed food & 163.876 & 179.087 & 163.574 & 165.720 \\
& & & & \\
\hline
\end{tabular}

Source: Author's CERD simulation

Table 7.10 Impact of WTO accession on food self-sufficiency

\begin{tabular}{lccc}
\hline & $\begin{array}{c}\text { Base rate } \\
\text { (per cent) }\end{array}$ & $\begin{array}{c}\text { Change } \\
\text { (per cent) }\end{array}$ & $\begin{array}{c}\text { Post accession rate } \\
\text { (per cent) }\end{array}$ \\
Rice & 97.6 & 0.282 & 97.9 \\
Wheat & 91.5 & -0.162 & 91.3 \\
Corn & 95.7 & -0.553 & 95.2 \\
Pulse & 110.0 & -0.122 & 109.9 \\
Other grains & 94.7 & -0.197 & 94.6 \\
Oilseeds & 75.9 & -0.983 & 75.1 \\
Vegetable \& fruit & 100.9 & 0.349 & 101.3 \\
Other crops & 99.7 & -0.002 & 99.7 \\
Livestock & 97.8 & 0.158 & 97.9 \\
Fishery & 111.4 & 0.105 & 111.5 \\
Processed food & 93.3 & -4.333 & 89.3 \\
& & & \\
Total grain & 95.1 & -0.063 & 95.0 \\
Total food & 96.9 & -1.548 & 95.4 \\
\end{tabular}

Source: Author's CERD simulation 


\section{Policy implications and conclusion}

The simulation results reported above show that agricultural sectors will be adversely affected by the WTO accession: agricultural output falls, grain and total food self-sufficiency rates decline, and rural-urban income inequality worsens. Although the magnitudes of the impacts are smaller than widely anticipated, the results may still give concern to policymakers. This section discusses policy options to tackle these adverse impacts.

A direct response to the impact may be to provide support to agricultural sectors and farmers. Support can be provided in many forms, with some conforming the WTO rules and others not. Chapter 6 (this volume) considers a scenario where the level of tariff cut on agricultural commodities is halved because of various forms of new barriers such as labelling requirements, reporting procedures, and so on. The simulation of this scenario using CERD indicates that although such a policy may provide some cushioning of agricultural sectors and help to ease the worsening trend of rural-urban income inequality, the overall welfare gain from WTO accession is smallerthe equivalent variation is 6 per cent less than that of the full tariff cut of the WTO accession commitments.

Here, support in the form of a production subsidy is considered. It is assumed that the government subsidises farmers at a level that would keep

Table 7.11 Changes in household income and welfare after WTO accession (per cent)

$\begin{array}{lccc}\text { Indicators } & \text { Eastern } & \text { Central } & \text { Western } \\ \begin{array}{l}\text { Real wages } \\ \text { Agricultural labour }\end{array} & 0.042 & -0.103 & 0.148 \\ \quad \text { Non agricultural labour } & 2.528 & 0.675 & 1.163 \\ \text { Real income } & & & \\ \quad \text { Rural household } & 1.196 & 0.539 & 0.681 \\ \quad \text { Urban household } & 1.772 & 0.742 & 1.174 \\ \text { Utility } & & & \\ \quad \text { Rural household } & 0.972 & 0.520 & 0.615 \\ \quad \text { Urban household } & 1.502 & 0.834 & 1.003\end{array}$

Source: Author's CERD simulation 
the grain self-sufficiency rate constant after the WTO accession. Simulation of CERD shows that it would cost 7.2 billion yuan to make up for the tiny reduction of 0.06 per cent in the grain self-sufficiency rate (Table 7.12). If the target were to restore the full decline in the total food self-sufficiency rate (1.5 per cent), the cost would be as high as 180 billion yuan.

Increasing transfer payments to inland regions was also simulated in Chapter 6 . The rationale behind this policy option is that because the economy as a whole benefits from the WTO accession, there is the possibility of transferring income from one group to another to make all sectors better off. However, the simulation gives a similar result to the scenario of halving the cut in agricultural tariffs. The improvement in regional and rural-urban household income disparity is achieved at the cost of lower overall welfare gains -1 per cent less welfare gain than the full tariff cut scenario. Increases in transfers to the inland regions are made possible through penalising the coastal regions that have a higher rate of return.

Another policy option is to increase agricultural research and development to improve agricultural productivity in China, as suggested by many authors, for example, Fan, Fang and Zhang (2001) and Hazell and Haddad (2001). Simulations of CERD were conducted to find out how much productivity improvement is required to keep the grain and food self-sufficiency rates constant after WTO accession. It was found that the required productivity improvement is 0.32 and 2.85 per cent, respectively, for constant grain and total food self-sufficiency rates. To give an idea about what these figures mean, agricultural TFP in the past may be used as a benchmark. According to Fan (1997), agricultural TFP was 5.1 and 3.91 per cent per annum during the periods 1978-84 and 1984-96. A 2.85 per

Table 7.12 Cost of restoring grain self-sufficiency to the pre-accession level (million yuan)

\begin{tabular}{lcccr}
\hline & & & & \\
EV (million yuan) & $2,117.987$ & $2,368.282$ & $2,686.207$ & $7,172.476$ \\
\hline
\end{tabular}

Source: Author's CERD simulation. 
cent productivity improvement implies that China should almost double the level of agricultural research and development.

Agricultural productivity may be improved through other channels. One such approach could be reforming the current land tenure system. It is often argued that the average farm size in China is too small to take full advantage of available economies of scale. Without well defined land ownership, farmers are reluctant to invest in land, and the lack of a land market impedes needed adjustments in China's rural economy (Lohmar and Somwaru 2002). However, secure land tenure is also important so that low-income farmers can have food security. Zhou (1998) finds that China's 'dual land system'4 is superior in terms of avoiding generating new landlessness and inefficient landholding. Further, Ho (2001) finds that many Chinese farmers prefer the current system, especially in poor villages, as it guarantees households access to land. FAO (2002, p.26) also shows that the poverty index is negatively related to land holding, and productivity is negatively related to farm size, that is, smaller farms have higher productivity. These findings may prompt second thoughts about the popular idea of increasing farm size, especially in poor regions.

Finally, further liberalisation is also an option. It was suggested in Chapter 6 that domestic market reform characterised by freer movement of primary factors and commodities may enhance overall welfare and improve regional income disparity.

In addition, China should promote trade liberalisation globally. China has made significant commitments in trade liberalisation of agricultural products and its protection of agriculture is among the lowest in the world. This puts China in a good position in the new round of trade liberalisation negotiations. GTAP simulations show that the removal of agricultural protection in OECD countries improves the competitiveness of Chinese agricultural products in world markets and increases the grain self-sufficiency rate (Yu and Frandsen 2002). 


\section{Notes}

1 For a review of broader agricultural policies in China, see Colby, Diao and Tuan (2001).

2 For an introduction to the evolution of these policies, see Jiang and Duncan (2001).

3 This seems a puzzle at first glance as the central region has the smallest reduction in almost all agricultural sectors among the three regions. However, as the magnitude of impact varies across sectors and the sectoral composition differs across regions, it turns out that the central region becomes the hardest hit region in the agricultural sector as a whole.

4 Land is divided into self-sufficiency land and responsibility land. Self-sufficiency land, or grain rations land, was equally contracted to households on a per capita basis for planting mainly grains for self-consumption. The responsibility land was contracted on the conditions of fulfilling state output quotas and paying agricultural taxes and fees.

\section{References}

Anderson, K., Jikun Huang, and lanchovichina, E., 2002. 'Long-run impacts of China's WTO accession on farm-nonfarm income inequality and rural poverty', Memo, Centre for International Economic Studies, University of Adelaide.

Brown, L., 1995. Who Will Feed China? Wake up Call for a Small Planet, Norton and Company, Washington, DC.

Colby, H., Xingshen Diao and Tuan, F. 2001. China's WTO accession: conflicts with domestic agricultural policies and institutions, TMD Discussion Paper No. 68, International Food Policy Research Institute, Washington, DC.

Fan, Shenggeng, 1997. 'Production and productivity growth in Chinese agriculture: new measurement and evidence', Food Policy, 22(3):21328.

Fan, Shenggeng, Cheng Fang and X. Zhang, 2001. How agricultural research affects urban poverty in developing countries: the case of China, Environment and Production Technology Discussion Paper 83, International Food Policy Research Institute, Washington, DC.

Food and Agriculture Organisation, 2002. The State of Food Insecurity in the World 2002, Food and Agriculture Organisation, Rome.

Food and Agriculture Organisation 2003. FAO STAT, Rome: Food and Agriculture Organisation, available at http://www.fao.org. 
Hazell, P. and Haddad, L., 2001. Agricultural research and poverty reduction, Food, Agriculture and the Environment Discussion Paper 34, International Food Policy Research Institute, Washington, DC.

Ho, P., 2001. 'Who owns China's land? Property rights and deliberate institutional ambiguity', China Quarterly, 166:394-421.

Jiang, Tingsong and Duncan, R. 2001. WTO accession and China food policy: a literature survey, Memo, National Centre for Development Studies, The Australian National University, Canberra.

Ke, Bingsheng, 1999. China's agriculture and policy facing WTO entry, Paper presented at International Agricultural Trade Research Consortium, China's Agricultural Trade and Policy: Issues, Analysis, and Global Issues, San Francisco, 25-26 June.

Lardy, Nicholas R., 2002. Integrating China into the Global Economy, Brookings Institution, Washington, DC.

Lin, Justin Yifu, 1997. 'Institutional reform and dynamics of agricultural growth in China', Food Policy, 22(3):201-12.

Lohmar, Bryan, 2002. 'Market reforms and policy initiatives: rapid growth and food security in China', Food Security Assessment, GFA-13, Economic Research Service, United States Department of Agriculture, Washington, DC:22-30.

Lohmar, Bryan and Somwaru, A., 2002. 'Does China's land-tenure system discourage structural adjustment?', China's Food and Agriculture: Issues for the 21st Century, AIB-775, Economic Research Service, US Department of Agriculture, Washington, DC:39-40.

Lu, Feng, 1997. Food trade policy adjustment in China and an evaluation of the risk of a food embargo, Working Paper C1997007, China Centre for Economic Research, Peking University, Beijing.

Nyberg, Albert J. and Rozelle, S., 1999. Accelerating China's Rural Transformation, World Bank, Washington, DC.

National Bureau of Statistics, 2002. Statistical Yearbook of China 2001, China Statistics Press, Beijing.

Yang, Yongzheng, 2000. Are food embargoes a real threat to China?, Memo, National Centre for Development Studies, The Australian National University, Canberra. 
Yu, Wusheng, and Frandsen, S.E., 2002. China's WTO commitments in agriculture: does the impact depend on OECD agricultural policies, Paper presented at the 5th conference on global economic analysis, Taipei, 5-7 June.

Zhang, $\mathrm{Ci}$ and Yong Li, 1998. '214 yi, haoda ge liangkuang kulong (21.4 billion: what a big hole for grain funds)', Cai Jing (Finance), October:12-17.

Zhou, Jian-Ming, 1998. Is nominal public but de facto private land ownership appropriate? Comparative study among Cambodia, Laos, Vietnam; Japan, Taiwan Province of China, South Korea; China, Myanmar; and North Korea, EUI Working Paper ECO No. 98/12, Economics Department, European University Institute, Florence.

Zhou, Zhangyue, 2001. 'Joining WTO and China's food security', Association for Chinese Economic Studies (Australia) Newsletter, 3. 